\title{
Змагальна діяльність біатлоністів високої кваліфікації на сучасному етапі розвитку біатлону
}

\section{Олексій Кравченко, Василь Карленко}

Національний університет фізичного виховання і спорту України, Київ, Україна

Анотація. У роботі розглянуто питання, що стосуються організаційних аспектів побудови змагальної діяльності біатлоністів високої кваліфікації на сучасному етапі розвитку біатлону. Мета. Розглянути чинники, що впливають на змагальну діяльність біатлоністів високої кваліфрікації та розвиток біатлону на сучасному етапі. Методи. Аналіз та узагальнення науково-методичної літератури, протоколів змагань. Результати. Авторами узагальнено фрактори та тенденції змагальної діяльності, впорядковано наявне співвідношення показників змагальної діяльності в розіграші Кубка світу, чемпіонатах світу та зимових Олімпійських іграх. За результатами дослідження висловлено застереження щодо доцільності подальшого розширення календаря міжнародних змагань та збільшення кількості змагальних дисциплін, оскільки їх реалізація заходиться на межі фізіологічних можливостей спортсменів. У дослідженні зроблено висновок про доцільність подальшого наукового обгрунтування удосконалення системи побудови змагальної діяльності біатлоністів високої кваліфікації шляхом розробки модельних характеристик та індивідуальних програм змагальної діяльності. Ключові слова: біатлон, змагальна діяльність, змагальні дисципліни, програма змагань.

\section{Oleksii Kravchenko, Vasyl Karlenko}

\section{COMPETITIVE ACTIVITY OF HIGHLY SKILLED BIATHLETES AT THE MODERN STAGE OF BIATHLON DEVELOPMENT}

Abstract. The paper considers issues related to the organizational aspects of designing competitive activity of highly qualified biathletes at the present stage of biathlon development. Objective. To consider the factors influencing the competitive activity of highly qualified biathletes and the development of biathlon at the present stage. Methods. Analysis and generalization of scientific and methodical literature, competition protocols. Results. The author summarizes the factors and trends of competitive activity, organizes the existing ratio of competitive activity indices in the World Cup, World Championships and Winter Olympics. According to the results of the study, reservations were made about the expediency of further expanding the calendar of international competitions and increasing the number of competitive disciplines, as their implementation goes beyond the physiological capabilities of athletes. The study concludes on the feasibility of further scientific substantiation for improving the system of designing competitive activity of highly qualified biathletes through development of the model characteristics and individual programs of competitive activity.

Keywords: biathlon, competitive activity, competitive disciplines, competition program.
Kravchenko 0, Karlenko V. Competitive activity of highly skilled biathletes at the modern stage of biathlon development. Theory and Methods of Physical education and sports. 2020; $3: 21-25$

DOI: $10.32652 /$ tmfvs.2020.3.21-25
Кравченко 0, Карленко В. Змагальна діяльність біатлоністів високої кваліфікації на сучасному етапі розвитку біатлону. Теорія і методика фрізичного виховання і спорту. 2020; 3: 21-25 DOI: 10.32652/tmfvs.2020.3.21-25
Вступ. У системі підготовки біатлоністів високої кваліфрікації до участі в розіграші кубків, чемпіонатів світу та зимових Олімпійських ігор важливе місце належить змагальній діяльності [10], яка щільно пов'язана зі спортивним результатом, що обумовлює необхідність постійного моніторингу їі структури і змісту, виявлення факторів і тенденцій, що визначають досягнення біатлоністами високої кваліфрікації значних спортивних результатів [5]. На неї певним чином впливає сучасна програма змагань, яка є організаційнометодичним алгоритмом для побудови підготовки на різних етапах спортивного удосконалення.

Формування програми змагань у біатлоні здійснювалося 3 початку організації перших осріційних міжнародних змагань та чемпіонатів світу, що проводилися з 1953 р. до 1967 р. Міжнародною федерацією сучасного п'ятиборства, з 1967 р. до 1998 р. Міжнародною фредерацією сучасного п'ятиборства і біатлону, а з 1999 р. і до сьогодні - Міжнародною спілкою біатлоністів (IBU) [13].

Процес її формування спирався на рішення зазначених організацій з урахуванням пропозицій національних федерацій і стратегії Міжнародного олімпійського комітету (МОК) з розвитку міжнародного олімпійського руху. Проте, аналіз науково-методичних і практичних матеріалів, що стосуються розвитку біатлону, показав, що серед фрахівців і організаторів цього виду спорту немає єдиної думки щодо принципів фрормування змагальних програм і складових її дисциплін. Також недостатньо вивчено вплив 30внішніх і внутрішніх факторів та тенденцій змагальної діяльності на спортивні досягнення біатлоністів високої кваліфікації.

Тому дослідження у зазначеному напрямі $€$ актуальними, що підтверджується їх потребою національної команди з біатлону. 
Дослідження виконано відповідно до наукової теми 2.14 «Теоретикометодичні основи підвищення технічної майстерності кваліфрікованих спортсменів у змагальних вправах (на прикладі легкої атлетики, зимових видів та велосипедного спорту» Зведеного плану науково-дослідної роботи у сорері фрізичної культури і спорту на 2017-2022 pp.

Мета дослідження - дослідити чинники, що впливають на змагальну діяльність біатлоністів високої кваліфікації та розвиток біатлону на сучасному етапі.

Методи дослідження: аналіз та узагальнення доступної науково-методичної літератури та мережі Інтернет, протоколів офріційних міжнародних змагань розіграшу Кубка і чемпіонатів світу, зимових Олімпійських ігор з біатлону.

Результати дослідження та їх обговорення. У ході дослідження для визначення впливу на змагальну діяльність біатлоністів високої кваліфрікації зовнішніх та внутрішніх факторів проведено аналіз матеріалів IBU та національних федерацій провідних країн світу, в яких біатлон знаходиться на високому рівні розвитку, рішень державних органів виконавчої влади з питань фрізичної культури і спорту та громадських організацій фрізкультурно-спортивної спрямованості України [1, 4, 11]. Це дозволило встановити найбільш вагомі зовнішні та внутрішні фрактори, що обумовлюють розвиток біатлону і впливають на систему тренування та змагальну діяльність кваліфрікованих біатлоністів.

До зовнішніх факторів належать: висока популярність біатлону у світі та посилена увага до його розвитку в країнах, що входять до складу Міжнародної спілки біатлоністів; інтенсифікація міжнародного та національних спортивних календарів; економічний стан розвитку країни; організаційні, фінансові, кадрові та матеріальнотехнічні можливості державних і громадських організацій; кліматогеографічні умови для розвитку цього виду спорту; сучасні інноваційні технології (методичні, медичні, антидопінгові); зростання матеріальних та моральних стимулів праці спортсменів та тренерів.

Внутрішні фрактори детермінують переважно ефективність системи тренування та змагальної діяльності біатлоністів високої кваліфікації. Їх визначення здійснювали на основі моніторингу даних науково-методичної літератури, власних наукових досліджень, проведених на контингенті біатлоністів збірних команд України, та досвіду практичної діяльності тренерів. Було встановлено, що до найбільш вагомих внутрішніх фракторів доцільно віднести: рівень здоров'я спортсменів; анатомо-срізіологічну структуру їхнього організму; генетичну схильність до заняття відповідним видом спорту; функціональні та резервні можливості організму; поточний та оперативний стан спортсменів; якість систем харчування, відновлення тощо.

Проведені дослідження показали, що зовнішні та внутрішні фрактори взаємозалежні і взаємопов'язані, потребують постійного моніторингу для виявлення відповідних тенденцій розвитку виду спорту, проблем змагальної діяльності та своєчасного застосування в системі тренування адекватних методичних підходів.

Аналіз діяльності IBU з проведення міжнародних змагань, результатів XVII (1994 р., Ліллегаммер, Норвегія), XVIII (1998 р., Нагано, Японія), XIX (2002 р. Солт-Лейк-Сіті, США), XX (2006 р., Турин, Італія), XXI (2010 р., Ванкувер, Канада), XXII (2014 р., Сочі, Росія) XXIII (2018 р., Пьончхан, Корея) зимових Олімпійськихігор, розіграшу Кубка світу і чемпіонатів світу 2011-2020 рр та інших офріційних змагань з біатлону свідчить про наявність чисельних тенденцій розвитку цього виду спорту та змагальної діяльності біатлоністів високої кваліфрікації. Виникнення нових тенденцій, як показали дослідження, обумовлено прийняттям організаційних рішень IBU щодо подальшого розвитку біатлону та удосконалення календаря міжнародних змагань, головними з яких сьогодні є такі:

- поступове збільшення від 57 (1993) до 69 (2018) країн-членів IBU яким надано рівні конституційні права й обов'язки з розвитку біатлону, про- ведення міжнародних змагань та інших заходів;

- розширення календаря міжнародних змагань, у результаті чого у програмі розіграшу Кубка світу (без урахування програми чемпіонату світу та Олімпійських ігор) кількість етапів збільшилася в спортивних сезонах із п'яти (1983/1984) до десяти (2020 /2021):

- збільшення загальної кількості стартів у спортивних сезонах з одного (1957/1958) до $38(2020 / 2021)$ та їх коливання від 32 (2013/2014) до 36 (2017/2018); кількості змагальних дисциплін у програмах розіграшу Кубка світу (з одної до восьми), чемпіонатів світу (з одної до семи), зимових Олімпійських ігор (з одної до шести);

- введення до програми розіграшу кубка світу 2014/2015 рр. нової спринтерської дисципліни - одиночна змішана естафетна гонка, показові виступи 3 якої уперше проведено 23 березня 2014 р. під час розіграшу фрінального етапу Кубка світу в Осло (Норвегія), а починаючи зі спортивних сезонів 2014/2015-2015/2016 рр. цей вид програми введено в національний залік розіграшу Кубків світу та IBU, a з сезону 2018-2019 рр. - введено до програми чемпіонату світу з біатлону;

- експериментальне проведення скороченої індивідуальної гонки 15 км, замість 20 км у спортивному сезоні 2018/2019 рр.;

- збільшення кількості учасників гонки 3 масового старту 330 до 60 спортсменів у спортивному сезоні 2018/2019 рр.;

- апробація нової змагальної дисципліни супер-спринт, що відбудеться у спортивному сезоні 2020/2021 рр. на десятому етапі розіграшу Кубка світу в м. Голменколлені (Норвегія);

- зростання конкуренції між країнами, спортсмени яких здобувають медалі на зимових Олімпійських іграх і чемпіонатах світу, а також залікові очки в національному та індивідуальному рейтингу розіграшу Кубка світу;

- посилення переважного впливу швидкості на дистанції на кінцевий результат в усіх видах змагальних програм у спортсменів, які посіли місця в шістці кращих на зимових Олімпійських іграх та у десятці - під 
Т а б л и ц я 1. Динаміка швидкості на дистанції провідних біатлоністів світу, що посіли 1-6-те місця на зимових Олімпійських іграх 1994-2018 рp., м · c-1

\begin{tabular}{|l|c|c|c|c|}
\hline \multirow{2}{*}{\multicolumn{1}{|c|}{ Дисципліна }} & \multicolumn{4}{|c|}{ Місце проведення, рік } \\
\cline { 2 - 5 } & $\begin{array}{c}\text { Лiллегаммер, } \\
\mathbf{1 9 9 4}\end{array}$ & $\begin{array}{c}\text { Ванкувер, } \\
\mathbf{2 0 1 0}\end{array}$ & Сочі, 2014 & $\begin{array}{c}\text { Пхьончхан, } \\
\mathbf{2 0 1 8}\end{array}$ \\
\hline 20 км, індивідуальна гонка & 5,98 & 6,97 & 6,76 & 7,03 \\
\hline 10 км, спринтерська гонка & 5,92 & 6,89 & 6,81 & 7,09 \\
\hline 12,5 км, гонка переслідування & & 6,23 & 6,18 & 6,3 \\
\hline 15 км, масовий старт & & 7,08 & 5,90 & 7,07 \\
\hline $4 \times 7,5$ км, естафета & 5,45 & 6,08 & 6,86 & 6,51 \\
\hline $\begin{array}{l}2 \times 6 \text { км + 2 × 7,5 км змішана } \\
\text { естафета }\end{array}$ & $*$ & $*$ & 6,4 & 5,52 \\
\hline X, середнє & 5,78 & 6,65 & 6,49 & 6,59 \\
\hline
\end{tabular}

* - змагання не проводились

час розіграшу загального заліку Кубка світу протягом спортивних сезонів 2010/2011-2019/2020 рр.;

- поступове підвищення результативності стрільби у переважній більшості видів змагальних програм;

- підвищення рівня мотивації спортсменів до тренувальної та змагальної діяльності із запровадженням системи заохочувальних спонсорських програм (виплата високих грошових винагород за участь у змаганнях, матеріально-технічне забезпечення спортсменів безкоштовним спортивним інвентарем, обладнанням та матеріалами для змащення лиж);

- використання неолімпійських дисциплін у програмах зимових та літніх змагань з біатлону;
- посилення Всесвітньою антидопінговою агенцією (ВАДА), медичним комітетом Міжнародної спілки біатлоністів (IBU) та національними антидопінговими центрами запобіжних антидопінгових заходів.

Спеціальні дослідження динаміки компонентів змагальної діяльності біатлоністів, шо посіли місця 3 1-го по 6-те на головних змаганнях - зимових Олімпійських іграх, таких як швидкість бігу по дистанції, результативність та швидкострільність стрільби свідчать про таке: суттєве підвищення швидкості пересування по дистанції в усіх видах змагальних дисциплін на зимових Олімпійських іграх 1994-2018рр. Наприклад, якщо діапазон швидкості у спринтерській та індивідуальній гон- ках у 1994 р. коливався в межах 5,92$5,98 \mathrm{M} \cdot \mathrm{c}^{-1}$, то у 2018 р. у цих дисциплінах зазначений показник коливався в діапазоні 7,03-7,09 м · c $^{-1}$. Аналогічна тенденція встановлена в гонці переслідування та масовому старті на XXI зимових Олімпійських іграх 2010 р. у Ванкувері (Канада), де у зазначеній дисципліні розіграно перш комплекти олімпійських нагород. Такі самі тенденції збільшення швидкості пересування по дистанції з 5,45 м · $\mathrm{c}^{-1}$ до $6,51 \mathrm{M} \cdot \mathrm{c}^{-1}$ спостерігаються в естафетній гонці. Поряд з цим, у змішаній естафеті спостерігається тенденція до суттєвого погіршення середньо швидкості пересування по дистанції $36,4 \mathrm{M} \cdot \mathrm{c}^{-1}\left(2014\right.$ р.) до $5,52 \mathrm{M} \cdot \mathrm{c}^{-1}$ (2018 р.), унаслідок впливу метеорологічних факторів на якість змащення лиж (табл. 1).

Подальші дослідження виявили поліпшення (стабілізацію) абсолютних показників результативності стрільби у всіх змагальних дисциплінах на зимових Олімпійських іграх 19942014 рр., крім 2018 р., де зареєстровано погіршення цього показника у більшості спортсменів у цілому, що, на думку фахівців та тренерів, зумовлено складними метеорологічними умовами (низька температура зовнішнього середовища, сильний вітер), специфрічними умовами проведення змагань у вечірні години зі штучним освітленням лижних трас та установок для стрільби (табл. 2).

Аналіз показника швидкострільності (час перебування спортсмена на вогневому рубежі) свідчить про його

Т а б л и ц я 2. Динаміка результативності стрільби у провідних біатлоністів світу, які посіли 1-6-те місця на зимових Олімпійських іграх 1994-2018рр., штрафні хвилини (кола)

\begin{tabular}{|c|c|c|c|c|c|c|c|}
\hline \multirow{2}{*}{ Дисципліна } & \multicolumn{7}{|c|}{ Місце проведення, рік } \\
\hline & $\begin{array}{l}\text { Ліллегаммер, } \\
1994\end{array}$ & $\begin{array}{l}\text { Нагано, } \\
1998\end{array}$ & $\begin{array}{l}\text { Солт- Лейк- } \\
\text { Сіті, } 2002\end{array}$ & $\begin{array}{l}\text { Турин, } \\
2006\end{array}$ & $\begin{array}{l}\text { Ванкувер, } \\
2010\end{array}$ & $\begin{array}{l}\text { Сoчi, } \\
2014\end{array}$ & $\begin{array}{l}\text { Пхьончхан, } \\
2018\end{array}$ \\
\hline 20 км, індивідуальна гонка & 2,17 & 1,66 & 1,00 & 1,67 & 1,17 & 0,67 & 1,00 \\
\hline 10 км, спринтерська гонка & 1,00 & 0,83 & 0,83 & 0,33 & 0,83 & 0,50 & 0,80 \\
\hline 12,5 км, гонка переслідування & * & * & 2,17 & 3,00 & 1,83 & 1,17 & 1,80 \\
\hline 15 км, масовий старт & * & * & * & 1,17 & 1,67 & 1,33 & 1,80 \\
\hline $4 \times 7,5$ км, естафета & 1,50 & 0,33 & 0,16 & 0,67 & 0,83 & 0,17 & 1,80 \\
\hline $\begin{array}{l}2 \times 6 \text { км +2 × 7,5 км змішана } \\
\text { естафета }\end{array}$ & * & * & * & * & * & 0,17 & без штафних кіл \\
\hline
\end{tabular}

* - змагання не проводились 
суттєву варіативність, що обумовлена впливом зовнішніх та внутрішніх факторів. Протягом змагань зимових Олімпійських ігор 2018 р. спостерігалося зменшення часу перебування спортсмена на вогневому рубежі до 18 c; мінімізація сумарного часу перебування на стрільбищі, що становив в індивідуальній гонці 1 хв 36 с, спринтерській гонці - 46 с, гонці переслідування - 1 хв 27 с, масовому старTi -1 XB 19 C.

Проведені дослідження змагальної діяльності біатлоністів високої кваліфікації свідчать також про збільшення відсотка спортсменів, які здатні демонструвати абсолютну результативність стрільби в різних змагальних дисциплінах та її високу швидкість, що не суперечить висновкам [8, 14].

3 урахуванням наведених даних та на підставі аналізу основних компонентів спеціальної підготовленості (швидкості на дистанції, результативності стрільби, швидкострільності), що притаманні провідним біатлоністам світу, можна розподілити їх на три групи:

- перша (елітна) - три-п'ять спортсменів, які володіють суттєвою перевагою над іншими у швидкості пересування по дистанції (від 15-35 с у спринтерській до 3-7 хв в індивідуальних та контактних дисциплінах), але поступаються їм у рівні стрілецької підготовленості;

- друга (середня) - 10-20 спортсменів, які здатні періодично демонструвати найвищі функціональні якості, проте мають постійну перевагу над елітною групою в показниках результативності та швидкості стрільби;

- третя (аутсайдери) - близько 80 спортсменів, які значно поступаються біатлоністам обох груп як у швидкості пересування по дистанції, так і в спеціальній стрілецькій підготовленості.

Нами також встановлено, що високий рівень стрілецької підготовленості, показниками якого є результативність стрільби та швидкострільність в умовах змагальної діяльності, не є вирішальними чинниками для здобуття перемоги.

Результати дослідження змагальної діяльності біатлоністів високої кваліфікації на сучасному етапі розвитку біатлону, становлення якої відбувається протягом тривалого часу [1, 2, 5, 9, 13], доповнюють висновки інших дослідників, що на змагальну діяльність в біатлоні впливають зовнішні та внутрішні фактори [2]. Сказане свідчить про те, що вона потребує постійного удосконалення із застосуванням нових технологій $[7,12]$ в межах фрізіологічних можливостей організму спортсменів [10].

Систематизовані нами зовнішні і внутрішні фрактори тенденції розвитку біатлону, що впливають на його розвиток та ефективність змагальної діяльності біатлоністів високої кваліфікації, не суперечать висновкам інших науковців та практиків і суттєво доповнюють їх зміст [2, 3, 6, 14].

y цілому, результати проведених досліджень проблем змагальної діяльності на сучасному етапі розвитку біатлону збігаються 3 висновками В. М. Платонова [10] щодо доцільності подальшого наукового обґрунтування цього напряму системи підготовки спортсменів в олімпійському спорті шляхом розробки модельних характеристик та індивідуальних програм змагальної діяльності.

\section{Висновки:}

1. Дослідження особливостей змагальної діяльності біатлоністів високої кваліфікації на сучасному етапі розвитку біатлону свідчать про наявні структурні зміни в системі її побудови в олімпійських макроциклах 2010/2014-2014/2018 рр., переважне посилення впливу на спортивний результат спортсменів, які посіли 1-6-те місця, функціонального компоненту їхньої спеціальної підготовленості, поступове поліпшення у переважної більшості біатлоністів результативності і швидкострільності та перманентний ступінь впливу зазначених компонентів на кінцевий результат (вирішальне значення лише у випадку недостовірної різниці у швидкості пересування спортсмена по дистанції) у всіх видах змагальних програм.

2. Змагальна діяльність на сучасному етапі розвитку біатлону обумовлена чисельними чинниками, найбільш впливовими 3 яких $€$ зовнішні й внутрішні фрактори та тенденції змагальної діяльності, що впливають на її структуру, зміст та спортивні досягнення біатлоністів високої кваліфрікації.

3. Зовнішні фрактори, до яких належать організаційні рішення IBU щодо розвитку біатлону, удосконалення календаря та програми міжнародних змагань, з одного боку, стимулюють подальший розвиток виду спорту, поліпшують структуру та зміст змагальної діяльності в біатлоні, а 3 іншого - створюють нерівні умови в організації підготовки спортсменів до участі в змагальній діяльності.

4. Внутрішні фрактори обумовлюють стан здоров'я, функціональні можливості організму, спеціальну підготовленість біатлоністів високої кваліфікації та детермінують якість їхньої змагальної діяльності.

5. Кількісні показники змагальної діяльності, що застосовуються на сучасному етапі розвитку біатлону, перевищують фрізіологічну межу можливостей спортсменів, тому потребують осмислення, постійного корегування та пошуку нових підходів до удосконалення системи її побудови.

Конфлікт інтересів. Автори заявляють, що відсутній будь-який конфолікт інтересів.

\section{ЛITEPATУРA}

1. Боярко Анатолій. Кубок світу з біатлону: від Рупольдінгу-1978 до Голменколлена-2019. Харків: Видавництво ФОП Панов А.М., 2020. $181 \mathrm{C}$.

2. Громыко ВФ, Солдатов ОА, Субботин ВЯ. Влияние лыжной гонки на точность стрельбы в биатлоне. Научно-спортивный вестник. 1987; 2 : 16-20.

3. Зубрилов РА, Карленко ВП. Пути совершенствования спортивно-технического мастерства биатлонистов. Проблемы биомеханики спорта. Тез. докл. VII Всесоюз. науч. конф.; Пенза, 3-6 окт. 1991 г. Москва: ВНИИФК; 1991. C. 180

4. Карленко ВП та ін. Цільовий підхід в системі тренування та змагальної діяльності кваліфрікованих біатлоністок. Фізична культура, спорт та здоров'я нації. 2015; 19 (2): 148-164.

5. Карленко ВП та ін. Змагальна діяльність біатлоністів високої кваліфікації як один із чинників підвищення їхньої технічної майстерності. Науковий часопис Національного педагогічного університету імені М. П. Драгоманова. 2019. с. 66-88.

6. Кравченко 0, Карленко В. Змагальна діяльність біатлоністів високої кваліфікації: проблеми та перспективи. Теорія і методика фрізичного виховання і спорту. 2018; 4: 15-24.

7. Михалев ВИ, Аикин ВА, Корягина ЮВ. Новые технологии совершенствования тренировочного процесса биатлонистов. Ученые за- 
писки университета имени П. Ф. Лесгафта. 2014; 3 (109): 118-124.

8. Мулик ВВ. Система багаторічного спортивного удосконалення в ускладнених умовах поєднання основних сторін підготовленості спортсменів (на матеріалі лижного спорту) [Автореферат]. Харків. 2001. 40 c.

9. Пидгрушна ЕM, Зубрилов РА. Особенности системы международных соревнований по биатлону на современном этапе. Современная система спортивной подготовки в биатлоне материалы II Всерос. науч.-практ. конфр. Омск, 29-30 апреля 2012 г. Омск. 2012. 127-131.

10. Платонов ВН. Система подготовки спортсменов в олимпийском спорте. Общая теория и ее практические приложения: учебник [для тренеров]: в 2 кн. Киев: Олимпийская лит., 2015. Кн. 1. c. 80-95.

11. Правила змагань з біатлону. Київ; Державний комітет України з фізичної культури та спорту; 1998.75 с.

12. Соснин АА, Тузов ВФ. Идеомоторная тренировка как метод повышения скорострельности и качества стрельбы в биатлоне. Лыжный спорт. 1985; 1:19.

13. IBU-DATACENTR. [Електронний ресурс]. Режим доступу: https://biathlonresults.com/

14. Iliev V. Structure of the results in the Biathlon and Shooting technique. IBU-UNESCO seminar. 2008, 2010.

\section{LITERATURE}

1. Boiarko A. Biathlon World Cup: from Ruhpolding-1978 to Holmenkollen-2019. Kharkiv: Vydavnytstvo FOP Panov A.M., 2020. 181 p.

2. Gromyko VF, Soldatov OA, Subbotin VY Impact of ski race upon shooting accuracy in biathlon. Nauchno-sportivny vestnik. 1987: 2: 16-20.

3. Zubrilov RA, Karlenko VP. Ways to improve the sports and technical skills of biathletes.
Problems of sports biomechanics. Tez. dokl. VII Vsesoyuz. nauch. konf.; Penza, 3-6 Oct. 1991. Moscow: VNIIFK; 1991. p. 180.

4. Karlenko VP et al. Targeted approach in the system of training and competitive activity of qualified biathletes. Fizychna kultura, sport ta zdorovia natsii. 2015; 19 (2): 148-164.

5. Karlenko VP et al. Competitive activity of highly qualified biathletes as one of the factors of improving their technical skills. Naukovyi chasopys Natsionalnoho pedahohichnoho universytety imeni M. P. Drahomanova. 2019. p. 66-88.

6. Kravchenko 0, Karlenko V. Competitive activity of highly qualified biathletes: problems and prospects. Teoriia i metodyka fizvykhovannia i sportu. 2018; 4: 15-24.

7. Mikhalev VI, Aikin VA, Koryagina YV. New technologies for improving training process of biathletes. Uchenyye zapiski universiteta imeni $P$. Lesgafta. 2014; 3 (109): 118-124.

8. Mulyk VV. The system of long-term sports improvement in complicated conditions of combining the main aspects of training of athletes (on the material of skiing) [Author's abstract]. Kharkiv. 2001. $40 \mathrm{p}$.
9. Pidgrushna EM, Zubrilov RA. Features of the system of international biathlon competitions at the present stage. Modern system of sports training in biathlon: materialy II Vseros. nauch.prakt. konf. Omsk, 29-30 Apr 2012. Omsk. 2012. 127-131.

10. Platonov VN. System of athletes' preparation in the Olympic sport. General theory and its practical applications: textbook [for coaches]: in 2 books. Kiev: Olimpiyskaya literatura, Book, 2015. Book 1. p. 80-95.

11. Biathlon competition rules. Kyiv; State Committee of Ukraine in Physical Culture and Sport; $1998.75 \mathrm{p}$

12. Sosnin AA., Tuzov VF. Ideomotor training as a method of increasing the rate of fire and the quality of shooting in biathlon.Lyzhny sport. 1985; $1: 19$.

13. IBU-DATACENTR. [Electronic resource] Access mode: https://biathlonresults.com/

14. lliev V. Structure of the results in the Biathlon and Shooting technique. IBU-UNESCO seminar. 2008, 2010

Надійшла 25.06.2020

\section{ІНФОРМАЦІЯ ПРО АВТОРІВ}

Кравченко Олексій https://orcid.org/0000-0001-9999-0187,_krava.a94@gmail.com Карленко Василь http://orcid.org/, skorpionsport50@gmail.com

Національний університет фізичного виховання і спорту України, 03150, Київ, вул. Фізкультури, 1

\section{INFORMATION ABOUT THE AUTHORS}

Kravchenko Oleksii https://orcid.org/0000-0001-9999-0187,_krava.a94@gmail.com Karlenko Vasyl http://orcid.org/, skorpionsport50@gmail.com

National University of Ukraine on Physical Education and Sport, 03150, Kyiv,

Fizkul'tury str., 1 